research. Moreover, many of the questions require progress in research methodology before the research itself can start.

None of this, however, will change anything much unless there is the political will to grasp the nettles of central government policy that affect health. The greatest potential of the white paper is that it could force the government's hand. The white paper is an unparalleled chance to make the NHS reforms work in the interests of the people's health. As health professionals we should seize this opportunity.

Professor of Public Health Medicine,

JOHN GABBAY

University of Southampton,

Wessex Institute of Public Health Medicine,

Winchester $\mathrm{SO} 225 \mathrm{DH}$

Secretary of State for Health. The health of the nation: a strategy for health in England. London HMSO, 1992. (Cm 1986.)

2 Delamothe T. Towards a healthier England. BMF 1992;305:135.

3 World Health Organisation. Alma Ata 1978. Primary health care. Geneva: WHO, 1978

4 World Health Organisation. Global strategy for health for all by the year 2000. Geneva: WHO, 1981.
5 Catford JC. Health targets. BMF 1991:302:980-1.

6 Lalonde M. A new perspective on the health of Canadians. Ottowa: Minister of Supply and Services, 1974.

US Public Health Service. Healthy people. Surgeon general's report on health promotion and disease prevention. Washington, DC: US Department of Health and Human Services, 1979.

8 Welsh Health Planning Forum. Strategic intent and directions for the NHS in Wales. Cardiff: Welsh Office, NHS Directorate, 1989.

9 New Zealand Government. A new relationship (includes New Zealand health goals and targets, health charter, and a contract for area health boards). Wellington: New Zealand Government Printing, 1989.

10 Northern Ireland Health Promotion Agency. Health promotion in Northern Ireland. A discussion paper. Belfast: Northern Ireland Health Promotion Agency, 1990.

11 Scottish Home and Health Department. Health education in Scotland - a national policy statement. Edinburgh: HMSO, 1991.

12 McGinnis JM. Setting objectives for public health in the 1990s: experience and prospects. Ann Rev Public Health 1990;11:231-49.

13 Jacobson B, Smith A, Whitehead M. The nations' health-a strategy for the 1990s. London: King Edward's Hospital Fund for London, 1991. (Revised ed.)

14 Faculty of Public Health Medicine of Royal College of Physicians. UK levels of health. London: Faculty of Public Health Medicine, 1991

15 Ashton J. The health of the nation. BMF 1991;302:1413-4.

16 Ashton J, Seymour H. The new public health. Milton Keynes: Open University Press, 1988.

17 Smith R. First steps towards a strategy for health. In: Smith R, ed. Health of the nation: the BMJ view. London: BMA, 1991

18 Research Unit in Health and Behavioural Change. Changing the public health. Chichester: John Wiley, 1989.

19 Stevens AJ, Gabbay J. "Needs assessment needs assessment...." Health Trends 1991;23:20-3.

20 Gabbay J. "Inspiring, politicking, plotting, cajoling...." BMF 1988;297:992.

\title{
What future for the regions?
}

\section{Only a single agency makes sense}

As the NHS reforms move into their second year the key question is, how will the market be managed? Little competition occurred in 1991-2 because ministers wanted a smooth take off for the reforms with no disruption before the election. By managing the market tightly the NHS Management Executive and the regional health authorities ensured a steady state. With the election out of the way purchasers and providers are beginning to change where services are provided. This is most evident in London, where several hospitals have failed to attract the contracts they need to maintain existing levels of services. Not surprisingly, purchasers are switching contracts to cheaper providers, and the acute sector in London is bound to shrink.

Similar changes are likely to occur elsewhere. The logic behind the reforms is that competition should be used to channel resources to efficient providers who are responsive to patients' needs and demands. It follows that inefficient and unresponsive providers will lose resources and have to cut back their services. Although competition may improve efficiency, the danger of an unregulated market is that access and equity might suffer. This might happen if purchasing decisions result in patients having to travel further to receive treatment or if resources are allocated to acute services at the expense of services for people with chronic conditions. To avoid these risks, a balance has to be struck between the incentives of the market and the need to take a strategic view of the distribution of health services. It is here that the role of regions is crucial. Ministers cannot manage the market directly from Whitehall - they must rely on an intermediate tier of management to oversee the activities of purchasers and providers and to deal with the consequences of failure of the market.

But what will this intermediate tier look like? As things stand, regional health authorities coexist with outposts of the NHS Management Executive, which were created last April to relate to NHS trusts on behalf of the management executive. The outposts were established partly because the management executive could not deal directly with the many trusts that came into existence in April and partly because trusts themselves did not want to relate to regional health authorities. In particular, many of those running trusts feared inappropriate controls by authorities perceived to be stuck in $\vec{\infty}$ the rut of old style NHS management.

The creation of outposts marks a further stage in the rise to power of the management executive. In the past three years $\overrightarrow{0}$ the executive has become firmly established as the head office for the NHS within the Department of Health. As such it has been used by ministers as a key tool for implementing government policies. At the same time the management executive has sought to become more effectively integrated with the NHS, partly through appointing managers such as $\stackrel{\odot}{\perp}$ Duncan Nichol to senior posts in the executive and partly $\overline{\vec{B}}$ through a deliberate strategy of working closely with NHS staff on developing and implementing national policies.

In this context the decision to set up outposts could be seen to prefigure the future role of the intermediate tier. In the longer term, having one regional organisation relating to providers (outposts) and another to purchasers (regional health authorities) makes little sense. If a coherent regional agency is to be created one option would be to build up the role of the outposts to enable them to perform the functions that are best carried out at a regional level in future.

These functions include allocating budgets to purchasers; $\mathcal{O}$ monitoring the performance of purchasers and providers and $\frac{D}{O}$ holding them to account; acting as a vehicle for transmitting and implementing national policies; and reporting back to the centre on the impact of policies on the ground, thereby shaping the emergence of new policies. And, to return to the starting point, the intermediate tier will also have an important role in managing the market. It is this role that is the least developed and little thought through. At a minimum 0 it encompasses arbitrating in disputes between purchasers

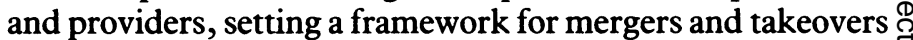
between purchasers and providers, taking a strategic view of $\stackrel{\AA}{\perp}$ health care needs and service developments, planning for education and research, and acting as the guardian of core 8 values - such as access and equity - as the market unfolds.

An alternative to building up the role of outposts would bec̄̄ to retain regional health authorities but to reduce their $\rightleftharpoons$ number to bring them into line with the configuration of outposts and to limit their scope. In this way, the developing skill of the outposts in managing providers could be combined 
in a single agency with the understanding that regional authorities have acquired of purchasers. The effect would be to create lean authorities, quite unlike the existing ones. Consistent with the spirit of the NHS reforms, as many functions as possible would be devolved or contracted out, enabling regional authorities to focus on their essential tasks.

Which of these options is adopted depends as much on politics and power as on logic and reason. On the one hand, many NHS trusts are likely to resist suggestions they should be brought back under the control of regional health authorities, even if these are radically reshaped. On the other hand, the regional health authorities (including regional chairmen) are certain to want to preserve a role for themselves in future. The views of ministers will therefore be particularly important.

Much hinges on whether ministers believe that it would be helpful to continue to have regional chairmen and nonexecutive members in place. Norman Fowler, when secretary of state for health social services, argued that meetings of regional chairmen acted as a health cabinet in which he could set directions for the NHS, explain the thinking behind government policies, and seek the view of the chairmen. If regional authorities did not exist this means of communication would be cut off and responsibility for implementing policies would rest entirely with managers. Although this would be consistent with the rise of managerialism in the past decade, it would deprive ministers of an independent channel of influence-and a political buffer. The removal of authorities at a regional level would also reduce the already limited participation of lay people in the running of the NHS.

Set against these factors, it can be argued that replacing regional health authorities by outposts of the management executive would have the effect of bringing into existence the clear chain of command heralded in Working For Patients. This would also formally recognise what has been happening over the past few years: regional health authorities have become de facto regional offices of the management executive, so tightly have their activities been controlled from the centre.

The main danger is of a messy compromise. The new ministerial team may instinctively dislike structural change and oppose reorganising the NHS yet again, but this should not prevent it thinking clearly about what arrangements are needed regionally to enable the NHS reforms to work to the best advantage. One way of squaring the circle would be to retain regional authorities but to insist that they adopt a style of working consistent with the new NHS. This option would not only result in a coherent regional approach, it would also force the management executive to review its relationship with regional health authorities to bring this into line with the emphasis on devolved responsibility for management. Whether those at the centre have the inclination to put their own house in order remains to be seen. The worst of all worlds would be to retain two separate regional agencies, neither of which would be capable of providing the overview needed to manage the market properly: it is essential that a single agency is responsible for relating to purchasers and providers.

CHRIS HAM

Professor,

Health Services Management Centre,

University of Birmingham,

Birmingham B15 2RT

\title{
Performance related pay for hospital doctors
}

\author{
So much for sticks, what about some carrots?
}

The General Medical Council's proposed new machinery for dealing with long term poor performance by doctors ${ }^{1}$ will mainly operate retrospectively. It is unlikely to reassure trust managers concerned about risk, who will want to secure better quality in advance. If at the same time they can increase productivity so much better. So it is not surprising to find that performance related pay is already on the agenda, with the doctors' and dentists' pay review body advocating discussion between the professions and the Department of Health, ${ }^{2}$ and the Central Consultants and Specialists Committee indicating its willingness to consider the issues. ${ }^{3}$

Several benefits are claimed for performance related pay. Firstly, it can be used to reward a good contribution (that is, the combined effect of effort and capability). Secondly, it enables managers to send powerful messages to people about whether they want them to stay. Thirdly, it forces managers to evaluate their staff. Perhaps, most importantly, it is said to motivate people to perform better. ${ }^{+}$Unfortunately, doubts exist about whether performance related pay delivers these benefits in practice ${ }^{5}$ and, in the short term at least, it is said to add to wage bills as benevolent managers class all their ducks as swans. ${ }^{6}$ But performance related pay is widespread in the private sector, and such doubts are unlikely to deter those anxious to experiment.

The real difficulties arise when considering how to measure performance. Essentially there are two measurements: inputs and outputs. Performance related pay based on outputs, such as piecework in factories or commission for sales staff, requires repetitive and homogeneous processes. The specialties most suited are surgery, anaesthesia, and diagnostic radiology. But even if reliable indices of output could be developed and agreed between managers and doctors, there would still be several reasons for caution.

These specialties have the highest earners from private practice, with the average practitioner more than doubling his or her NHS salary. ${ }^{7}$ The incentives would need to be sufficiently high to compete for their time, and the additional costs may well exceed any advantages from increased productivity. Complaints about shortages of other vital inputs, such as theatre time, would have added verve when voiced by surgeons whose income was directly threatened. Add to this the possible damage to quality of raising productivity (as in the British car industry in the 1960s) and conflict among practitioners fighting for a share of a limited pool of incentive money, and it is easy to see why even the most ardent proponent of performance related pay might hesitate.

If systems based on output are unattractive what about basing payments on individual input? This has the advantage that all specialists, not only surgeons and anaesthetists, may be included. But most professionals will agree to have their work judged only by peers; accurately assessing input in many medical jobs is fraught with difficulties.

Could the distinction award system be reformed to satisfy the strongest supporters of performance related pay (such as some trust managers) while retaining the support of the profession? There is already a consensus that the process 